\title{
IMPLEMENTATION OF THE LITERACY MOVEMENT IN SOCIETY
}

\author{
Yulianah Prihatin ${ }^{1}$, Arisni Kholifatu A.S. ${ }^{2}$ \\ Fakultas Ilmu Pendidikan, Universitas Hasyim Asy’ari \\ Corresponding Author: ${ }^{1}$ yuliaana553@gmail.com
}

\begin{abstract}
The low interest in reading in Indonesia requires educational institutions to create innovations to help increase people's interest in reading. In 2011, based on data from the World's Most Literate Nations, Indonesia was in 60th place regarding the reading interest of its population. The order is classified as low compared to other countries. Currently, the government has created the National Literacy Movement as an effort to increase the percentage of people's reading interest. However, it needs to be supported by many parties. Based on this, the KKNT team in the village of Marmoyo made an innovation to establish a Smart House so that people love reading more, especially reading fairy tales to their children. Fairy tales are a form of folklore that develops both orally and in writing. Regions in Indonesia have thousands of fairy tales that deserve to be preserved, this is because the younger generation knows and knows the developing fairy tales. In addition, the activity of reading fairy tales to children (ndongeng) is proven to be able to instill character and create closeness between parents and children. The method for this service is carried out by analyzing partner situations, reviewing literature / references related to the PKM theme, implementing fairy tale reading training with an interesting method in the village of Marmoyo for two days, cultivating reading fairy tales through a smart house. The fairy tale reading training program and the application of the Smart House in the village of Marmoyo are proven to be able to change the people's mindset about the benefits of fairy tales, and make it easier for people to find reading material.
\end{abstract}

Keywords: Implementation, literacy, society

\section{IMPLEMENTASI GERAKAN LITERASI PADA MASYARAKAT}

\begin{abstract}
Abstrak
Rendahnya minat baca di Indonesia, mengharuskan lembaga pendidikan menciptakan inovasi untuk membantu menaikkan minat baca masyarakat. Pada tahun 2011 berdasarkan data dari World's Most Literate Nations, Indonesia berada pada urutan ke 60 tentang minat baca penduduknya. Urutan itu tergolong urutan yang rendah dibandingkan negara-negara yang lainnya. Saat ini pemerintah sudah membuat Gerakan Literasi Nasional sebagai bentuk upaya menaikkan persentase minat baca masyarakat. Namun hal itu perlu didukung oleh banyak pihak. Berdasarkan hal tersebut, tim KKNT di desa Marmoyo membuat inovasi untuk mendirikan Rumah Pintar agar masyarakat semakin gemar membac, terutama membacakan dongeng untuk anak-anaknya. Dongeng merupakan salah satu bentuk dari cerita rakyat yang berkembang baik secara lisan maupun tulis. Daerah di Indonesia memiliki ribuan dongeng yang patut untuk dilestarikan, hal tersebut dikarenakan agar generasi muda mengenal dan mengetahui dongeng yang berkembang. Selain itu, kegiatan membacakan dongeng pada anak (ndongeng) terbukti mampu menanamkan karakter dan menciptakan kedekatan antara orang tua dan anak. Metode pada pengabdian ini dilakukan dengan cara analisis situasi mitra, Pengkajian pustaka/referensi yang terkait dengan tema PKM, pelaksanaan Pelatihan membaca dongeng dengan metode yang menarik di desa Marmoyo selama dua hari, pembudayaan membaca dongeng melalui rumah pintar. Progam pelatihan membaca dongeng dan penerapan Rumah Pintar di desa Marmoyo terbukti mampu mengubah pola pikir masyarakat tentang manfaat dongeng, serta memudahkan masyarakat dalam mencari bahan bacaan.
\end{abstract}

Kata Kunci: Implementasi, literasi, masyarakat 


\section{PENDAHULUAN}

Pada tahun 2011 berdasarkan data dari World's Most Literate Nations, Indonesia berada pada urutan ke 60 tentang minat baca penduduknya. Urutan itu tergolong urutan yang rendah dibandingkan negara-negara yang lainnya. Membaca merupakan aktivitas yang dapat meningkatkan wawasan berpikir dan memperluas pengetahuan seseorang, karena buku atau bahan bacaan merupakan alat komunikasi masyarakat berbudaya dan berperan penting dalam kehidupan sosial. Menurut Rahim (2001:163) membaca juga meliputi informasi tekstual yang dihubungkan dengan istilah skemata menunjukkan kelompok konsep yang tersusun dalam otak seseorang yang berhubungan dengan objek, tempat, tindakan atau peristiwa. Dengan membaca juga dapat megetahui sejarah suatu bangsa, kejadian masa lampau atau yang tentang kejadian menarik lainnya (Munaf, 2002:241). Salah satu jenis teks yang dapat dibuat sebagai bahan bacaan dan memiliki nilai karakter ang bagus untuk perkembangan anak adalah Dongeng. Dongeng merupakan salah satu bentuk cerita rakyat yang jumlahnya ratusan di Indonesia. Bascom (Danandjaja, 2007:50) menguraikan bahwa cerita rakyat dapat

dibagi menjadi tiga yaitu: mite, legenda, dan dongeng. Dongeng merupakan bagian dari tradisi lisan yang pernah hidup dan menjadi milik masyarakat yang diwariskan secara lisan dan turun-temurun. Dongeng merupakan buah pikiran leluhur bangsa yang mengandung pesan. Pada dongeng diketahui sejarah, pengalaman, pandangan hidup, adatistiadat, politik, cita-cita, dan kegiatan lain yang terdapat di suatu daerah.
Dongeng mengandung nilai-nilai budaya, agama, pendidikan, sosial dan lain-lain.Pada saat ini, eksistensi dongeng terutama dongeng daerah terkalahkan dengan cerita dari luar negeri. Generasi muda lebih mengenal cerita cinderella dibandingkan dengan cerita tentang asal-usul daerah. Perkembangan teknologi yang semakin canggih secara tidak langsung menggeser keberadaan dongeng yang sudah lama berkembang di masyarakat. Sangat sedikit anak-anak masa ini yang mendengarkan dan mengapresiasi dongeng yang ada di daerahnya. Mereka merasa asing dengan kebudayaan lokal yang ada di daerahnya. Padahal, jika dikaji lebih dalam, setiap cerita rakyat mengandung banyak falsafah hidup, nilai-nilai positif dan karifan lokal yang melatarbelakangi kehidupan mereka yang dapat dimanfaatkan sebagai cerminan kehidupan dimasa mendatang.

Salah satu upaya agar generasi muda lebih mengapresiasi dongeng adalah pengoptimalan melalui keluarga. Orang tua dan keluarga memiliki peran yang sangat pentig dalam pengenalan dongeng pada anak. Pembudayaan membaca dongeng di lingkungan keluarga dapat meningkatkan hubungan yang baik antara orang tua dan anak. Selain itu, pembiasaan membaca dongeng di keluarga diharapkan mampu mendukung program pendidikan karakter yang dicanangkan oleh pemerintah. Pendidikan karakter adalah upaya-upaya terencana dan terperinci yang dilaksanakan secara sistematis dan berkesinambungan untuk membantu anak dalam mengimplementasikan nilai-nilai kebaikan yang berhubungan dengan hubungan manusia dengan Tuhan 
Yang Maha Esa, diri sendiri, sesama manusia lainnya, lingkungan, bangsa dan negara yang diwujudkan dalam pikiran, perasaan, sikap, perkataan, dan perbuatan.

Pada kenyataanya, banyak keluarga, terutama orang tua tidak mengetahui pentingnya budaya membaca dongeng untuk anak, seperti di Desa Marmoyo. Desa Marmoyo terletak di kecamatan Kabuh, Kabupaten Jombang. Salah satu desa lokasi KKNT Universitas Hasyim Asy'ari. Kuliah Kerja Nyata Tematik (KKNT) dirancang sebagai salah satu pengabdian perguruan tinggi kepada masyarakat lewat penyuluhan, pembimbingan, pendampingan, dan lain-lain untuk membantu meningkatkan kualitas hidup berbagai lapisan masyarakat. Mahasiswa dibimbing oleh DPL untuk membuat Program kerja kelompok yang mana dibagi menjadi perdivisi antara lain keagamaan, pendidikan, kewirausahaan, kelembagaan, dan kesehatan. Setiap kelompok divisi menyusun program utama, pendukung, dan bantu untuk dijalankan serta diterapkan di masyarakat. Desa Marmoyo memiliki 1 masjid, 2 musholah, 1 SD, 1 TK/PAUD, 1 Puskesdes. Letak Desa Marmoyo berada di tengah hutan jati yang pada saat musim kemarau masyarkat kesulitan mendapatkan air karena kekeringan. Program Desa di Marmoyo diawali dari musyawarah Dusun yang dilanjutkan ke musyawarah Desa yang dihadiri oleh tokoh-tokoh masyarakat, tokoh Agama, RT/RW, Pemerintah Desa beserta BPD dalam rangka penggalian gagasan. Dari penggalian gagasan tersebut dapat diketahui permasalahan yang ada di Desa dan kebutuhan apa yang diperlukan oleh masyarakat sehingga aspirasi seluruh lapisan masyarakat dapat tertampung. Berdasarkan hasil observasi, $90 \%$ orang tua di desa Marmoyo tidak pernah membacakan dongeng pada anaknya.

Beberapa alasannya yaitu sulitnya sumber belajar yang berhubungan dengan dongeng dan kurangnya pengetahuan masyarakat tentang pentingnya membacakan dongeng pada anak. Perlu adanya solusi dan usaha dalam menghadapi masalah yang dialami oleh masyarakat desa Marmoyo. Beberapa solusi disiapkan oleh tim dosen pembimbing lapangan (DPL) KKNT Universitas Hasyim Asy'ari dan mahasiswa yaitu pertama, memberikan pelatihan cara membaca dongeng yang baik pada masyarakat desa Marmoyo. Kedua, melakukan pembudayaan membaca dongeng dengan menyediakan fasilitas rumah pintar agar masyarakat desa Marmoyo tidak mengalami kesulitas mencari dongeng. Rumah pintar merupakan lokasi dimana masyarakat dengan mudah dapat mengakses berbagai macam buku dongeng, dan dapat meminjam untuk digunakan di rumah. Berangkat dari masalah mitra serta solusi yang ditawarkan, maka kami mengangkat tema pengabdian masyarakat dengan judul "Penanaman Budaya Membaca Dongeng Melalui Rumah Pintar di Desa Marmoyo".

\section{METODE PENELITIAN}

Metode pelaksanaan PKM (Program Kemitraan Masyarakat) ini adalah sebagai berikut:

1. Analisis Situasi Mitra;

2. Pengkajian pustaka/referensi yang terkait dengan tema PKM;

3. Pelaksanaan Pelatihan membaca dongeng dengan metode yang 
menarik di desa Marmoyo selama dua hari;

4. Pembudayaan membaca dongeng melalui rumah pintar.

Lebih lengkapnya metode pelaksanaan pengabdian kepada masyarakat (PKM) yang dilakukan di desa Marmoyo untuk mengatasi masalah yang dialami oleh mitra akan dipaparkan secara rinci sebagai berikut

\section{Analisis situasi Mitra}

Pada tahap ini sudah dilakukan analisis situasi di desa Marmoyo. Kegiatan ini bertujuan untuk mengetahui permasalahanpermasalahan yang terjadi di desa Marmoyo saat ini. Jika permasalahan sudah diketahui maka langkah selanjutnya adalah dengan merencanakan solusi yang terbaik untuk mitra dalam mengatasi permasalahan yang terjadi. Berikut hasil analisis situasi mitra yang dilakukan dengan wawancara dan survey, yaitu :
a. Budaya membaca dongen masyarakat Desa marmoyo masih sangat rendah
b. Minimnya fasilitas untuk mencari dongeng

2. Pengkajian pustaka/referensi yang terkait dengan tema PKM

Kegiatan ini bertujuan untuk mengambil langkah dalam memberikan solusi terbaik bagi mitra. Pemberian solusi ini bukan hanya asal tanpa dasar yang kuat. Namun, sudah didasarkan pada para ahli. Adapun solusi yang ditawarkan untuk mengatasi permasalahan mitra menjadi tema pada PKM ini yaitu "Pelatihan dan Pembudayaan Membaca Dongeng melalui Rumah Pintar di Desa Marmoyo".
3. Pelaksanaan Pelatihan di desa Marmoyo selama dua hari

Tahap ini merupakan tahap pelatihan pada masyarakat tentang cara membaca dongeng agar menarik perhatian anak-anak.

4. Pembudayaan Membaca dongeng Pada tahap ini, masyarakat sudah mulai dibiasakan membacakan dongeng pada anak. Masyarakat dapat mengakses rumah pintar untuk mendapatkan buku dongen. Rumah pintar di tempatkan di balai desa Marmoyo. Pembudayaan ini berlangsung selama program KKNT di desa Marmoyo.

\section{HASIL DAN PEMBAHASAN}

Pengabdian ini berkaitan dengan pelatihan membaca dongeng dan penerapan Rumah Pintar sebagai sarana untuk membudayakan membaca di kalangan masyarakat desa Marmoyo. Berdasarkan hasil wawancara , masyarakat desa Marmoyo jarang mendongeng untuk anaknya. Hal tersebut dikarenakan tidak ada waktu, tidak paham pentingnya mendongeng untuk tumbuh kembang anak, serta susahnya akses untuk mendapatkan contoh-contoh dongeng.

Kegiatan pelatihan pada PKM ini akan dilaksanakan selama 2 hari dengan kolaborasi antara tim dosen dan mahasiswa. Hari pertama, semua peserta pelatihan akan diberikan pemahaman tentang pentingnya membaca. Hari kedua, peserta pelatihan dibagi menjadi tiga kelompok, masing-masing kelompok akan dibimbing oleh pemateri yang berbeda. Pada hari kedua ini, peserta pelatihan sudah mulai dibimbing untuk membaca dongeng dengan metode yang menarik agar anak-anak menyukai. 
Adapun untuk evaluasi selama pelaksanaan PKM dilakukan menggunakan angket yang akan dilaksanakan pada akhir pelatihan dan dua bulan setelah penerapan pos literasi (mading). Keberlanjutan program PKM ini juga akan terus dipantau oleh para tim Dosen dan mahasiswa agar pencapaian solusi kepada mitra dalam mengatasi permasalahan bisa maksimal. Target Pengabdian ini adalah masyarakat desa Marmoyo paham tentang pentingnya membacakan dongeng pada anak, mengetahui metode yang menarik untuk membaca dongeng, masyarakat desa Marmoyo menjadi terbiasa untuk membacakan dongeng dan juga mudah dalam mencari dongeng.

Masyarakat desa Marmoyo
sangat antusias dengan adanya
program Rumah Pintar. Data
diperoleh dari angket dan hasil
wawancara dengan warga. Selama dua bulan, Rumah Pintar menjadi salah satu tempat favorit bagi warga maupun anak-anak untuk berkumpul di hari minggu pagi atau sore hari. Selama dua bulan dilakukan program Rumah Pintar, sekitar 60\% masyarakat sudah gemar mendongeng untuk anak-anak di rumah. Data tersebut diperoleh melalui angket yang disebar pascapelaksanaan. Rumah Pintar terbukti menjadi akses masyarakat untuk mencari bahan bacaan (dongeng) dengan mudah.

\section{SIMPULAN}

Keberadaan Rumah Pintar menjadi salah satu alternative bagi warga untuk menghabiskan waktu membaca dongeng. Masyarakat juga antusias dengan diadakannya program pelatihan membaca dongeng, sehingga mereka mengetahui cara atau metode membaca dongeng yang menarik. Selama dua bulan, Rumah Pintar menjadi salah satu tempat favorit bagi warga maupun anak-anak untuk berkumpul di hari minggu pagi atau sore hari. Selama dua bulan dilakukan program Rumah Pintar, sekitar 60\% masyarakat sudah gemar mendongeng untuk anak-anak di rumah. Data tersebut diperoleh melalui angket yang disebar pascapelaksanaan. Rumah Pintar terbukti menjadi akses masyarakat untuk mencari bahan bacaan (dongeng) dengan mudah.

\section{DAFTAR PUSTAKA}

Danandjaja. 2007. Foklore Indonesia, Ilmu Gosip, Dongeng dan lain-lain. Jakarta: Pustaka Utama Grafiti.

Munaf, Y. 2002. Upaya Meningkatkan Minat Baca Siswa. Jurnal Pendidikan Bahasa Sastra dan Seni, 3 (2):241-250.

Rahim, F. 2001. Pengajaran Membaca Pemahaman Berdasarkan Teori Skema Komposisi. 